\title{
Impact of chess training in students with Attention Deficit Hyperactivity Disorder
}

\author{
Fereshteh Amouzadeh $^{1}$, Peyman Honarmand ${ }^{1}$, Seyede Samira Hoseini ${ }^{1}$, Hasan Gharayagh Zandi ${ }^{2}$, \\ Mehdi Rahimzadeh ${ }^{1}$ \\ 1-PHD Student, Department of Motor Behavior and Sport Psychology, Tehran University, Tehran, Iran. \\ 2- Assistant professor, Department of Motor Behavior and Sport Psychology, Tehran University, Tehran, Iran. \\ Corresponding Author: Fereshteh Amouzadeh \\ E-mail: Zamouzadeh@yahoo.com
}

Received: 30/07/2020

Accepted: 18/10/2020

\begin{abstract}
Introduction: One of the most common childhood disorders considered by psychologists and psychiatrists is Attention Deficit/Hyperactivity Disorder, which leads to attention deficit, hyperactivity and impulsivity in affected people.

Aim: The purpose of this study was to investigate the impact of Chess training in students with ADHD.

Method: The statistical community of the present quasi-experimental study was 76 students with ADHD in Khorramabad city in the academic year of 2019-2020. 32 students were selected by convenience sampling and randomly divided into two groups of 16 controls and experiments based on age, sex and pre-test results. And the experimental group received chess training for 11 consecutive weeks and a weekly session of 60 to 90 minutes. Subjects were evaluated three times (pre-test, post-test, two-week follow-up) with Connors and Swanson questionnaires and data were analyzed by ANOVA and Bonferroni test and Spss 21 software.

Results: The results of the study showed a direct and high correlation between the results obtained from both Swanson and Connors measuring instruments and the positive effect of chess training on students with ADHD. ( $\mathrm{P}=0.001, \mathrm{~F}=20.17)$.

Conclusions: Due to the positive effect of Chess training on the symptoms of ADHD, it is suggested that Chess training be used to reduce the symptoms of ADHD.

Keywords: Attention-Deficit/Hyperactivity disorder, Psycho-educational interventions, Students
\end{abstract}

How to cite this article : Amouzadeh F, Honarmand P, Hoseini SS, Gharayagh Zandi H, Rahimzadeh M. Impact of chess training on the of ADHD symptoms in students with Attention Deficit Hyperactivity Disorder. Shenakht Journal of Psychology and Psychiatry. 2020; 7 (5): 65-79 . URL: http://shenakht.muk.ac.ir/article-1-853-en.pdf

Copyright ( 92018 the Author (s). Published by Kurdistan University of Medical Sciences. This is an open access article distributed under the terms of the Creative Commons Attribution-Non Commercial License 4.0 (CCBY-NC), where it is permissible to download, share, remix, transform, and buildup the work provided it is properly cited. The work cannot be used commercially without permission from the journal. 


\title{
اثربخشى آموزش شطرنج در دانش آموزان مبتلا به بيش فعالى / نقص توجه
}

\author{
فرشته عموز اده'، ييمان هنر مند'، سمير احسينى'، حسن غراياق زندى'، مهدى رحيم زاده' \\ ا.دانشجوى دكترى تخصصى، گروه رفتار حركتى و روانشناسى ورزشى، دانشكاه تهران، تهران، ايران. \\ r. استاديار، كروه رفتار حركتى و روانشناسى ورزشى، دانشكاه تهران، تهران، ايران. \\ ايميل:yahoo.com \\ مولف مسئول: فرشته عموزاده
}

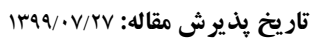

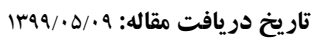

جكيده

مقدمه: يكى از رايجترين اختلالات دوران كودكى مورد توجه روانشناسان و روانيزشكان، اختلال نقص توجه / بيش فعالى است كه

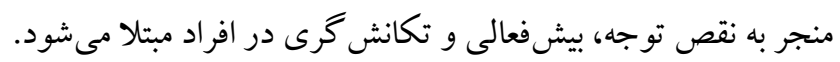

هدف: يزوهش حاضر با هدف بررسى اثربخشى آموزش شطرنج در دانش آموزان مبتلا به اختلال بيش فعالى / نقص توجه بود.

روش: جامعه آمارى يثزوهش نيمه تجربى حاضر، V9 نفر دانش آموز مبتلا به اختلال بيش فعالى همراه با نقص توجه شهرستان خرم آباد

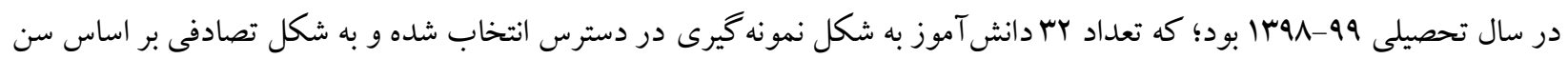

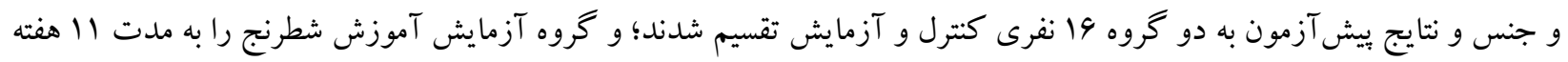

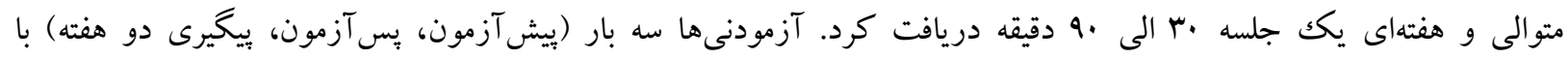

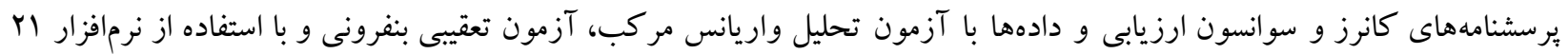
SPSS

يافتها: نتايج حاصل از يزوهش نشان دهندهى همبستكى مستقيم و بالايى بين نتايج به دست آمده از هر دو ابزار اندازهيرى

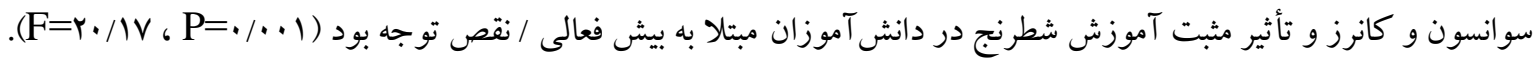
نتيجه كيرى: با توجه به تأثير مثبت آموزش شطرنج بر علائم بيش فعالى / نقص توجه بيشنهاد مى إد از آموزش شطرنج براى كاهش علائم بيش فعالى / نقص توجه استفاده شود. كليدوازهها: اختلال بيش فعالى / نقص توجه، مداخلات روانشناختى آموزشى، دانش آموزان 
درمانهاى دارويى، به فرد مبتلا داروهايى مانند محر كکها

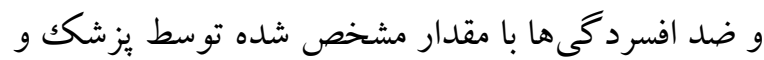
براى مدت زمان مشخصى مىدهند و در درمانهاى رفتارى و شناختى از روشهاى غير دارويى مثل برنامه تشويق زتونى و ... براى كاهش نشانهاى بيش فعالى / كم

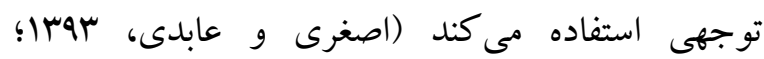

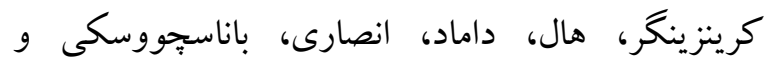
بويتلار V، 19 19). برخى از درمانهايى كه براى كاهش علائم اين اختلال توصيه مىشود عبارتاند از: رزيمهاى خوراكى، تمرينات بدنى، تمرين تمركز، آموزشهاى ديدارى، گفتو گوهاى دو به دو، روان درمانى هاى نهرين فردى، دارو درمانى و بازى درمانى را نام برد (جنتيان، نورى، شفتى، مولوى، سماواتيان، MNV فروهليج، لينج، باكس، ردوين، هاكان،

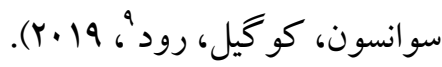
داروهاى مورد استفاده در دارو درمانى اثرات جانبى مانند بىخوابى خفيفى، بىاشتهايى، خلل در رشد و نمو كودك، اختلالات دستكاه گوارش، خشكى دهان، افزايش فشار خون، افزايش ضربان قلب، بىنظمى قلبى، بىقرارى، سردرد، تهش قلب، سراسيمگى و بى تابى، كيجى و نكرانى دارند (اصغرى و همكاران، سهبا؛

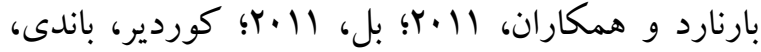

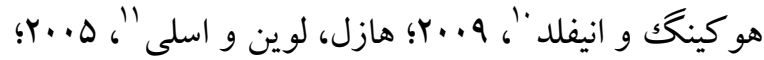

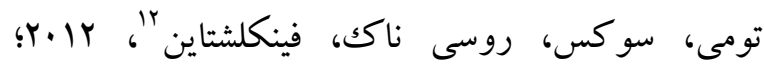

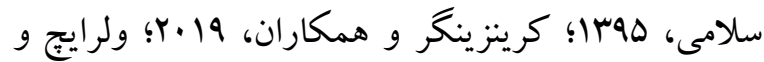

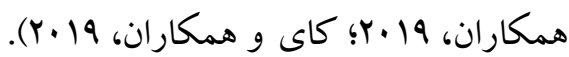

${ }^{7}$ - Krinzinger, Hall, Groom, Ansari, Banaschewski, Buitelaar

${ }^{8}$ - Wolraich, Chan, Froehlich, Lynch, Bax, Redwine, Hagan

9 - Caye, Swanson, Coghill, Rohde

${ }^{10}$ - Cordier, Bundy, Hocking, Einfeld.

${ }^{11}$ - Hazell, Lewin, Sly

${ }^{12}$ - Toomey, Sox, Rusinak, Finkelstein

\section{مقلدمه}

اختلال بيش فعالى / نقص توجه' كه قبل از V سالكى قابل تشخيص است بيشترين فراوانى را در دوران كودكى و نوجوانى به خود اختصاص داده است (انجمن روان

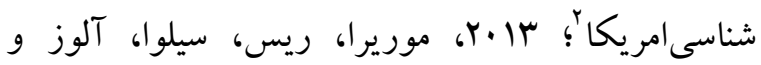

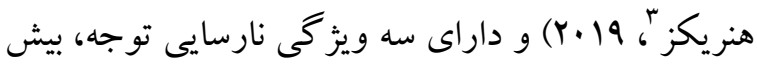

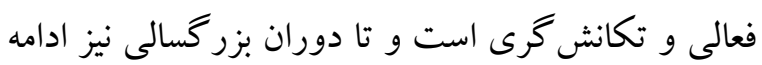

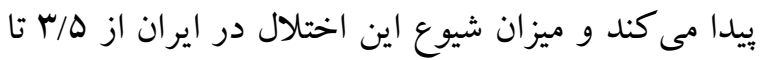

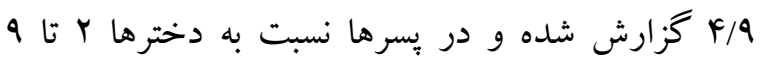
برابر شايعتر است(عموزاده، حسنوند، هاشميان و حمايت طلب، هوسا). كود كان مبتلا به اين اختلال از مشكلات رفتارى گوناگون (مانند اعتماد به نفس بايين، برخاشخرى و مشكلات آموزشى) رنج مىبرند و اغلب حداقل به يك إك اختلال، همبود ديخر نيز مبتلا هستند (بارنارد، سولاكك

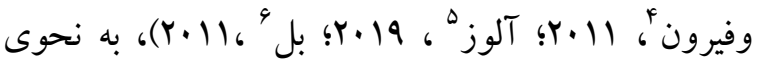
كه براى بسيارى از دانش آموزان، مشكلات جشمخيرى ايجاد مى كند و بر عملكرد شناختى اجتماعى، هيجانى و

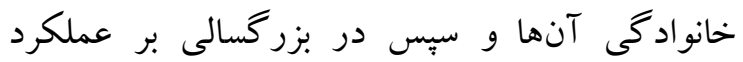
شغلى و زناشويى آنها تأثير مى گذارد اين اختلال در نتيجه تعاملات بيجيده بين زنتيك، محيط و عوامل زيستى (مانند آسيبهاى مغزى، بيمارىهاى عصبى، حساسيت به مواد غذايى و متغيرهاى محيطى) به وجود مى آيد ؛ اما سبب شناسى و درمان اين اختلال هنوز به طور كامل مشخص نشده است.( سلامى، هوبr) براى كنترل علائم اين اختلال، از درمانهاى دارويى و

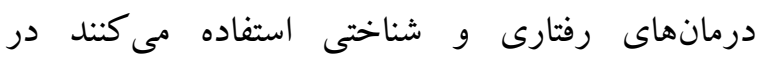

\footnotetext{
1- Attention-deficit hyperactivity disorder(ADHD)

${ }^{2}$ - American Psychological Association)APA)

3 - Moreira, Reis, Silva, Alves \& Henriques

${ }^{4}$ - Barnard, Sulak \& Fearon

5 - Alves

${ }^{6}$ - Bell
} 


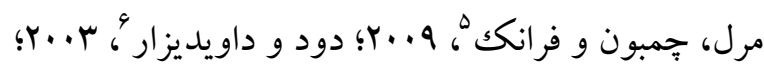

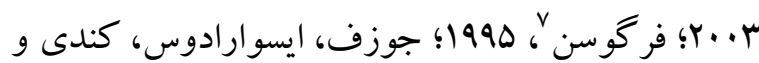

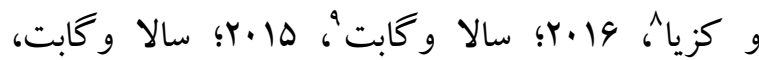
19+r.

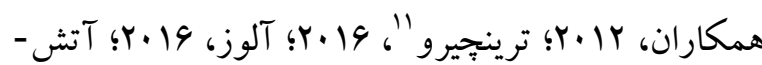

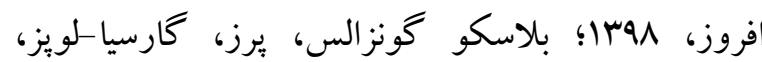

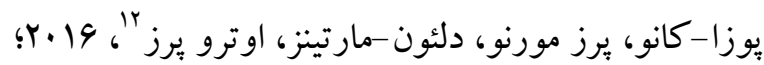
دى جود، كورا، ليند، هرناندرز- بونيلا، كوردوبا، وزلينگ جوز و همكاران، 19+r؛ موريرا و همكاران، 19 19ب؛

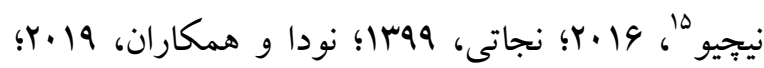
يريرا، كاسترو، ويلافاينا، كارواليو سانتوس، فوئنتس

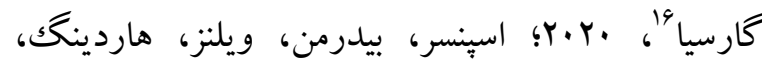

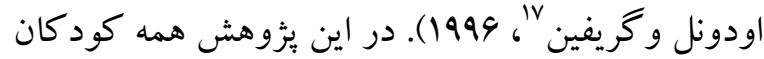
هفتهاى | جلسه ·r الى ·9 دقيقه، در مدت || هفته متوالى زير نظر يك مربى شطرنج و در كروههاى حداكثر f ن نفرى با استفاده از سيستم هوشمند (تابلو هوشمند، رايانه و صفحه آموزشى شطرنج) آموزش داده شدند.

اكثر تحقيقات انجام شده، نشان داده است كه درمانهاى دارويى، شناختى، بازى درمانى و فعاليت بدنى (عموزاده

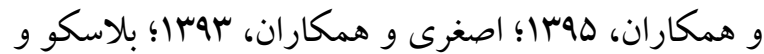

5- Demily, Cavézian, Desmurget, Berquand-Merle, Chambon and Franck

${ }^{6}$ - Dowd and Davidhizar

7- Ferguson

${ }^{8}$ - Joseph, Easvaradoss, Kennedy and Kezia

9 - Sala and Gobet

${ }^{10}$ - Sala, Gorini and Pravettoni

${ }^{11}$ - Trinchero

12- Blasco-Fontecilla, Gonzalez-Perez, Garcia-Lopez, Poza-Cano, Perez-Moreno,de Leon-Martinez and Otero-Perez

13- De Joode, Mora, Lindh, Hernández-Bonilla,Córdoba, Wesseling, Mergler

${ }^{14}$ - El Daou, and El-Shamieh

15 - Nechio

${ }^{16}$ - Pereira, Castro, Villafaina, Carvalho Santos and Fuentes-García

${ }^{17}$ - Spencer, Biederman, Wilens, Harding, O'donnell and Griffin
بازى وسيله بيان و ارتباط كودكك است و به عقيده

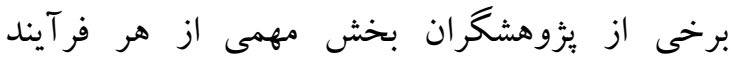
درمانكرى را تشكيل مىدهد. دسته بندىهاى مختلفى براى بازى مطرح شده است. يكى از برطرفدارترين آنها، طبقهبندى بيازه است بيازه بازىها را به ب دسته كلى بازىهاى تمرينى، بازىهاى نمادين و بازىهاى

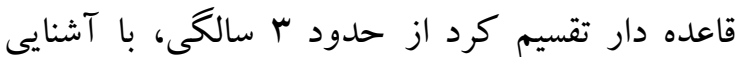
كودك با قواعد زندگى و يذيرش دستورات اخلاقى و قوانينى كه بزركت ترها وضع مى كنند، بازىهاى قاعده دار شكل مى گيرد. اين بازىها در حدود ·ل و و نيم

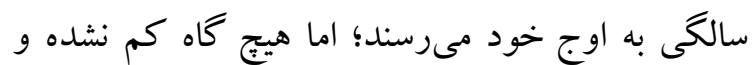
علاقه به انجام آنها تا سنين بزرگسالى و و حتى كهنسالى در انسان باقى مىماند. منج و ماريله، قايمموشك، لىلى و شطرنج از اين نوع بازىها هستند (سيل سيور، هامون بيما و ويير خائفى، سوبا!؛ جوز،

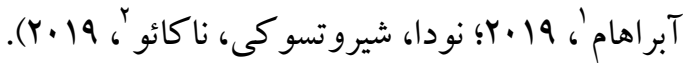
شطرنج فعاليت ذهنى بيجيجيدهاى است كه نياز به تعقل، تمر كز و قدرت تصميم گيرى بالا دارد. شطرنج در طول زندكى مسئوليت بذيرى و تصميم گيرى را به كود كان آموزش مىدهد. شطرنج ازجمله بهترين و مؤثرترين ابزار در آماده كردن كودكان براى مواجهه با دنياى كنونى است كه روز به روز با دنيايى از اطلاعات مواجه مىشود و همراه با آن موقعيتهاى دشوارترى در تصميم كيرى به به رون به

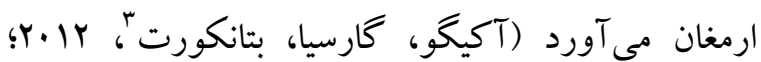

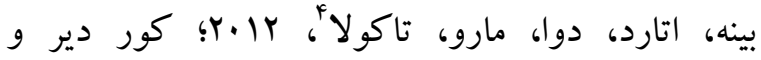

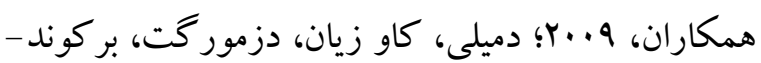

\footnotetext{
1- Jose S, Abraham

2 - Noda, Shirotsuki, Nakao

3 - Aciego, García, Betancort

${ }^{4}$ - Binev, Attard-Montalto, Deva, Mauro,Takkula
} 
اثربخشى آموزش شطرنج بر علائم بيش فعالى همراه با

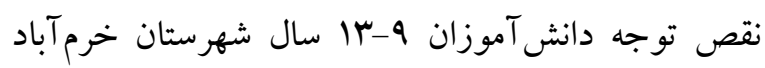

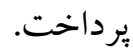

روش

روش يزووهش حاضر از نوع شبه تجربى است و جامعه

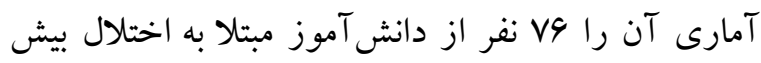
فعالى همراه با نقص توجه شهرستان خرمآباد در سال تحصيلى 99-1هr| تشكيل دادند كه ·r نفر از طريق مراجعه به مركز مشاوره و روانشناختى آموزش و يرورش استان لرستان، و4 نفر از طريق مطبهاى روانيزشكى و ·r نفر از طريق ارسال فرم سنجش كانرز معلم به مدارس و سبس، فرم سنجش كانرز

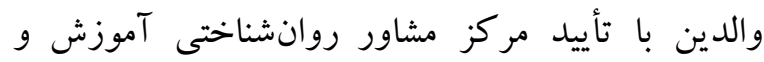
يرورش شهرستان خرمآباد انتخاب شدند. از اين تعداد، rr نفر به شكل نمونه گيرى در دسترس و بر اساس شرايط يزشكى (آيا دارو مصرف مى كند يا خير؟)، رشته ورزشى (تمرين يككرشته حداقل ץ روز در هفته و حداقل سابقه ا سال فعاليت در آن رشته) و رضايت والدين انتخاب گرديدند. معيارهاى محروميت از اين يثزوهش معلوليتهاى حسى و حركتى (ماند نابينايى، ناشنوايى)، بيمارىهاى عصبى مهم (مانند صرع)، بيمارى

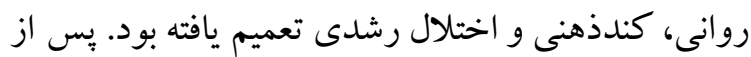
انتخاب آزمودنىها و در نظر كرفتن شرايط مورد نياز (خانه شطرنج، مربى و وسايل موردنياز) و بر اساس سن و و جنسيت و انجام ييش آزمون كه به وسيله ابزار كانرز و و ونائ سوانسون انجام شد آزمودنىها به دو گروه آندان 19 نفرى كنترل و آزمايش تقسيم شدند و گروه آزمايش در أندام

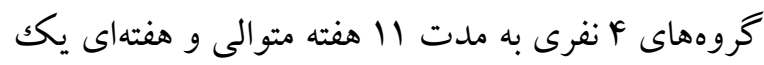

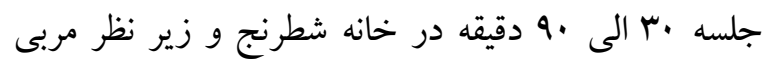

همكاران، 19.r؟؛ جنتيان و همكاران، TrAV هوسا؛ سيلسيور و همكاران، ها •ب؟ ولرايج و همكاران،

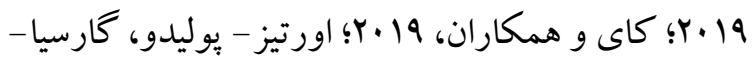

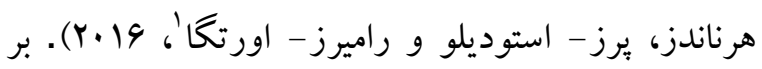
كاهش نشانهاى بيش فعالى / نقص توجه مؤثر بودهاند. شايان ذكر است كه تحقيقات كمى خصوصاً در ايران

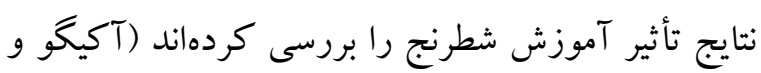

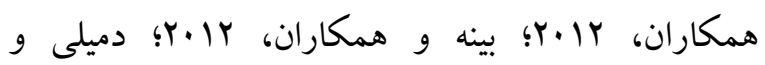

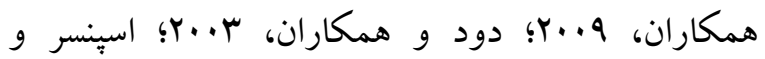

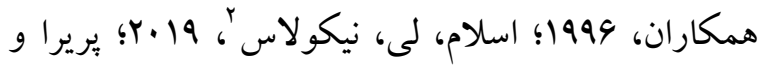

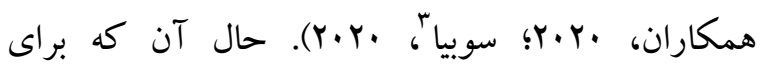
بررسى كارايى اين رويكرد، انجام حنين تحقيقاتى لازم است؛ بنابراين با توجه به تأثير بيش فعالى بر عملكرد

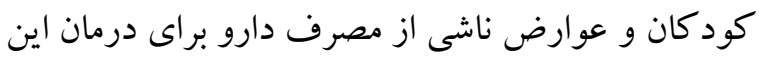
كودكان و جون بازى به تقويت و بازيرورى اجزاى إنى شناختى كمكك مى كند و كودكان به بازى و سركرمى باري علاقه فراوانى نشان مىدهند و همجِنين با توجه به اين كه كه شطرنج نحوه تفكر منطقى و كارآمد را آموزش مىدهد

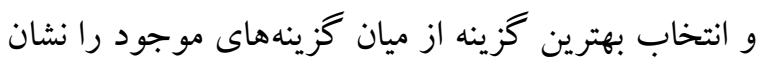
مىدهد و اهميت برنامه انعطافيذير، تمركز و نتيجه

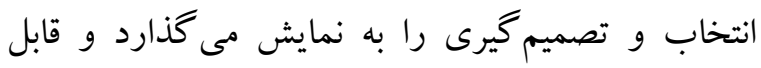
استفاده در مدارس با كمترين امكانات هستند و از اصول

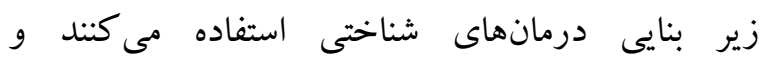
درمانهاى شناختى بر كاهش علائم بيش فعالى / نقص آنس توجه مؤثر بوده است، اين يرسش مطرح شد كه آيا

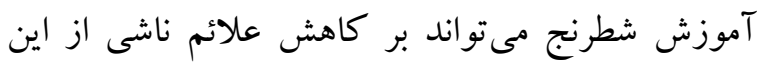

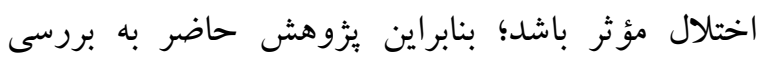

1. Ortiz-Pulido, Ortiz-Pulido, García-Hernández, Pérez-Estudillo and Ramírez-Ortega

${ }^{2}$ - Islam, Lee and Nicholas

${ }^{3}$ - Subia and et al 
بر گيرنده F سؤال (سن، جنسيت، رشته و سابقه فعاليت ورزشى) بود، استفاده كرديد.

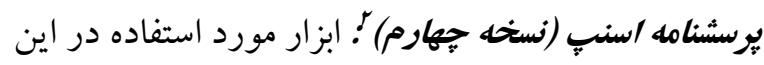

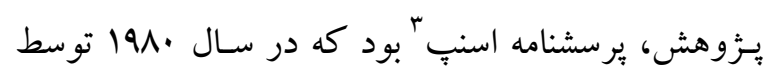

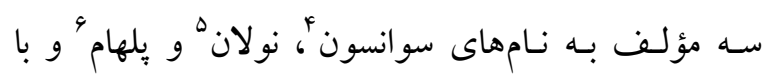

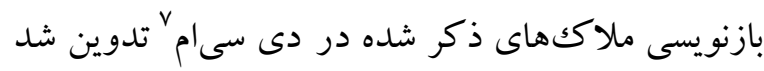

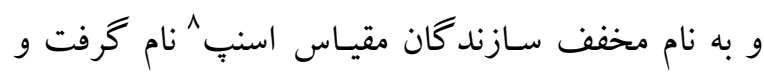
هم زمان با تجديد نظر در ملاككهاى دى سىام و تدوين

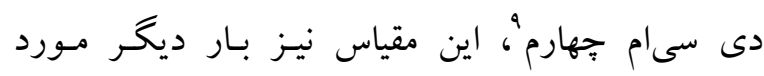

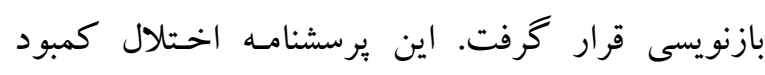

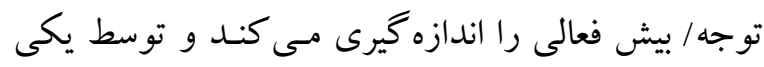
از دو مرجع مرتبط با كودكك (والـدين يـا معلم) تكميل

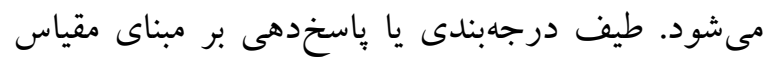

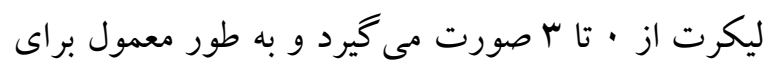
تعيسين افراد در معـرض خطر بيش فعالى / نقص توجه

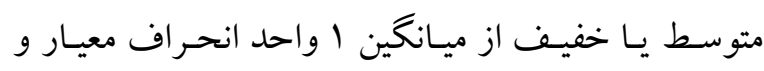
بر اي تعيسين افراد برخطر بيش فعالى / نقص توجه شديد

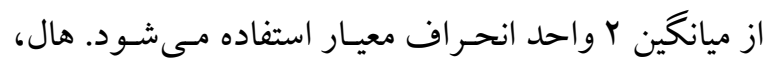

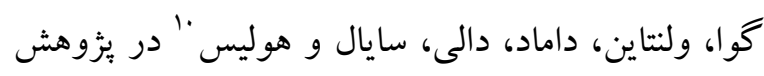
خود بر كود كان با علائم كمبود توجه/ بيش فعالى نشان

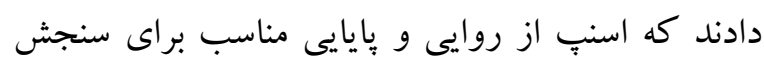
بيش فعالى برخوردار است ( هال و همكاران، 19 •r). همجنين روايى محتوا اين مقياس مورد تأييد متخصصان

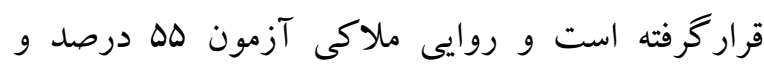
ضريب يايايى به روش باز آزمون برابر با M د درصد،

${ }^{2}$ - Swanson, Nolan \& Pelham Scale-Fourth (SNAP-IV)

3 - SNAP-IV

4- Swanson

5 - Nolan

${ }^{6}$ - Pelham

7- DCM

- SNAP

9 - IV-DSM

${ }^{10}$ - Hall, Guo, Valentine, Groom,Daley, Sayal and Hollis
شطرنج با استفاده از سيستم هوشمند (تابلو هوشمند، رايانه و صفحه آموزشى شطرنج آهنربايى) به آموزش شطرنج

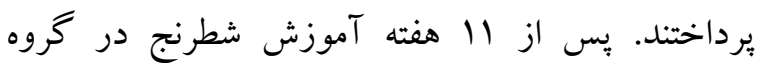
آزمايش، هر گرووه به طور مجدد مورد بررسى قرار كرفت. اين بررسى همانند بررسى اول در شرايط يكسان (زمان و فضاى يكسان) و توسط ابزار كانرز و سوانسون

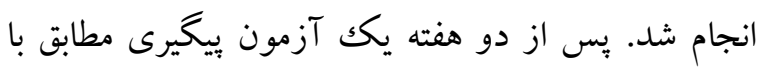

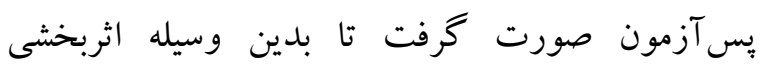
مداخله آموزش شطرنج در بازه زمانى بيشترى بررسى شود. لازم به ذكر است كه مراحل اجراى مطالعه مورد

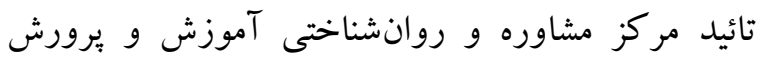
استان لرستان قرار كرفت. همجنين به شركت كند كان (والدين كودكان) توضيحات لازم در ارتباط با هدف يثزوهش داده شد. به منظور تجزيه و تحليل دادهها از نرمافزار SPSS نسخه اب در دو بخش آمار توصيفى و استباطى استفاده شد. همجنين، به منظور سازماندهى، خلاصه كردن و طبقهبندى نمرات خام و نيز توصيف اندازههاى نمونه، آمار توصيفى (فراوانىها، ميانكينها، انحراف استاندارد و رسم جداول) به كار رفت. آزمون شاييرو - ويلكك نيز جهت بررسى نرمال بودن دادهها مورد

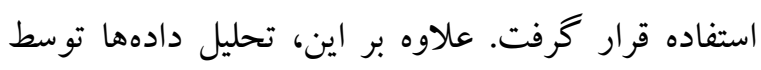
آزمون تحليل واريانس مركب و آزمون بييكردى بنفرونى انجام شد و اندازه تأثير براى هر مقياس محاسبه شد.

ابز ار فرم مشخصات دموكرافيك ': براى جمع آورى اطلاعات

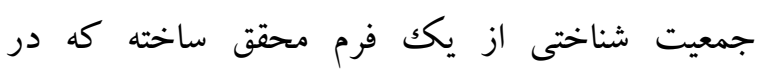

${ }^{1}$ - Demographic profile form 
كودك بيشتر خواهد بود. كانرز و همكاران بِايايى اين

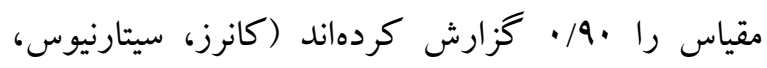
ياركر و ايشتين ، 1991؛ دى جود و همكاران، 19 (Y). همجِنين بِايايى اين برسشنامه از سوى موسسه علوم

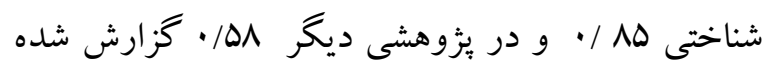
است. ( سبزوارى، ارشم، بروين بور، لهوبا).

\section{يافته ها}

كروه آزمايش، شامل 9 پِر و V دختر بود در حالى كه

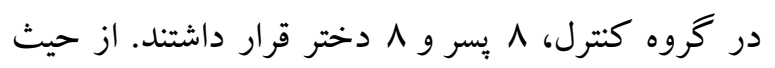
رشته و سابقه فعاليت ورزشى، در گروه آزمايش 4 نفر رشته ورزشى كاراته، 9 نفر زيمناستيك و \& نفر تكواندو و در گروه كنترل 9 نفر رشته ورزشى كاراته، V نفر زيمناستيك و r نفر تكواندو بود. ميانخين و انحراف

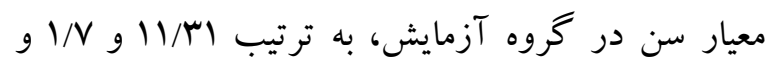

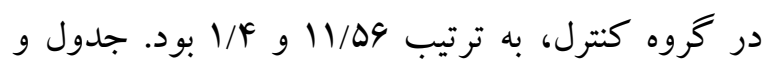
نمودار ا ميانگين و انحراف استاندارد مربوط به نمرات آزمون كانرز و سوانسون را در كروههاى آزمايش و و كنترل نشان مىدهد.
آلفـاى كرون باخ برابر ه ه/ • و ضريب حاصل از دونيمه كردن سل درصد گز ارش شده است (كيانى و هاديان فرد، (Irat مقياس درجهبندى كانزز (فرم والدين): مقياسهاى درجهبندى كانرز، فرم معلم و والدين در سال 1999 به منظور كمكك به شناسايى كودكان بيش فعال توسط كانرز، سيتارنيوس، پياركر و إشتين ' طراحى شد؛ اما يثزوهشهاى دهههاى اخير نشان دادهاند كه اين مقياسها براى مشخص كردن مشكلات رفتارى ديخر نيز مفيد هستند. طى صدها كار بُزوهشى و جند دهه كاربرد بالينى، روشن شد كه مقياس درجهبندى كانرز در كاربردهاى غربالكرى كلى براى اختلالها و مشكلات كودكى مفيد هستند و در صورت تركيب اطلاعات حاصل از معلم و والدين براى دستيابى به ارزيابى تشخيصى كامل، مى توانند سودمند باشند مقياس درجهبندى كانرز والدين در سال 1999 از سوى كانرز و همكاران استاندارد شده است. فرم والدين مقياس كانرز داراى צr سؤال است كه والدين كودكك آن را تكميل مى كنند. محدوده سنى مورد استفاده در مقياس هاى كانرز ب تا IV سال است كه هنجار سنى جداكانه با فواصل سنى س سال براى دختران و يسران تهيه شده است. تكميل اين برسشنامه ه- • ل1 دقيقه طول مى كشد. براى ارزشيابى در اين آزمون مىتوان

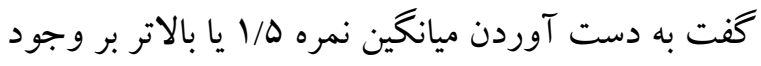
اختلال نقص توجه و بيش فعالى دلالت دارد؛ بهعبارتديخر، اين وبرسشنامه بو سؤال داشته ؛ لذا نمره

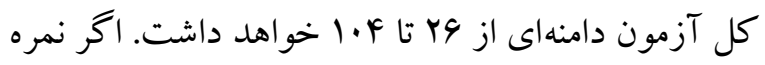
كودك بالاتر از ب به دست بيايد، بيانكر اختلال نقص توجه است. هر جه امتياز بالاتر رود، ميزان اختلال

1. Conner's Parents rating of childhood behaviour problems-CPRS$\mathrm{R}$

${ }^{2}$ - Conners, Sitarenios, Parker \& Epstein 


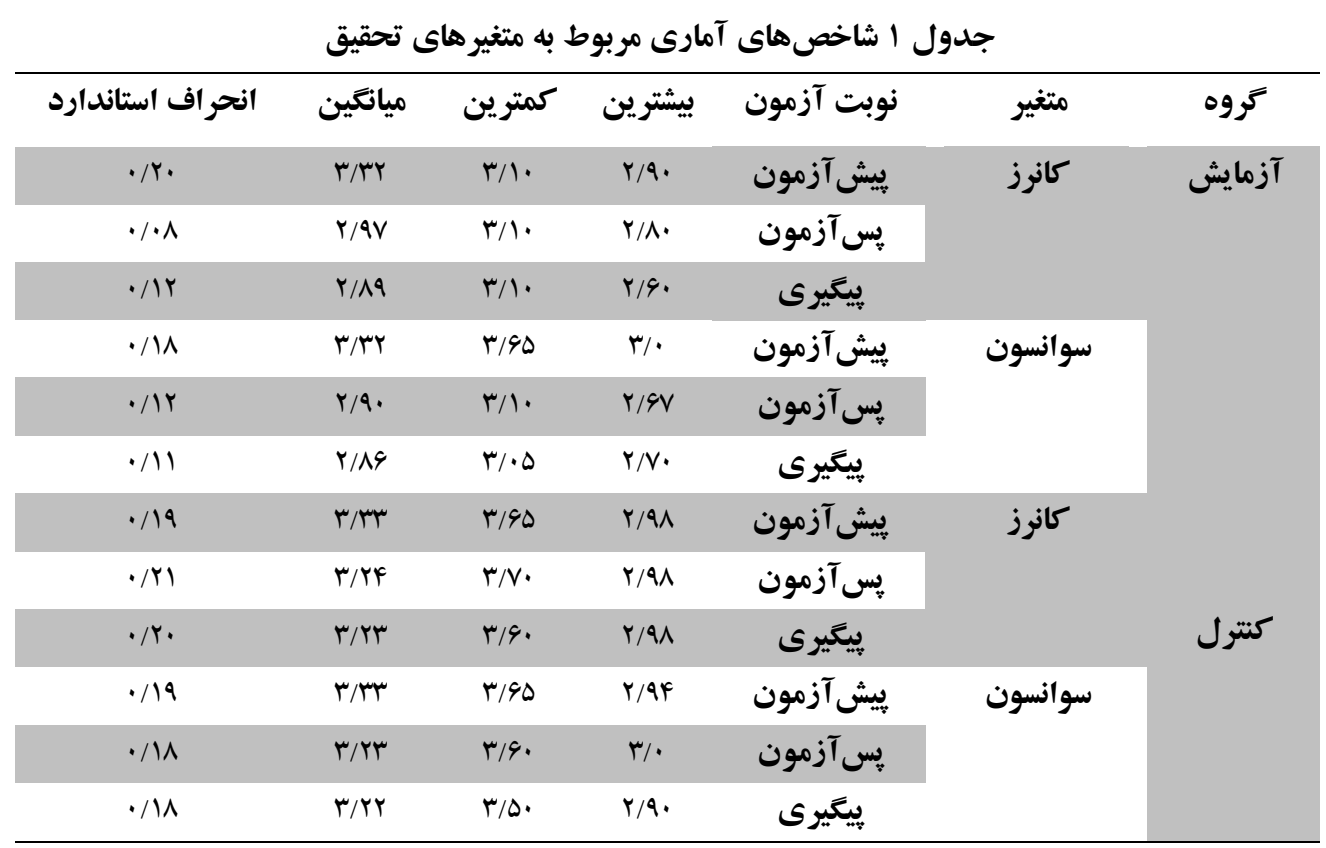

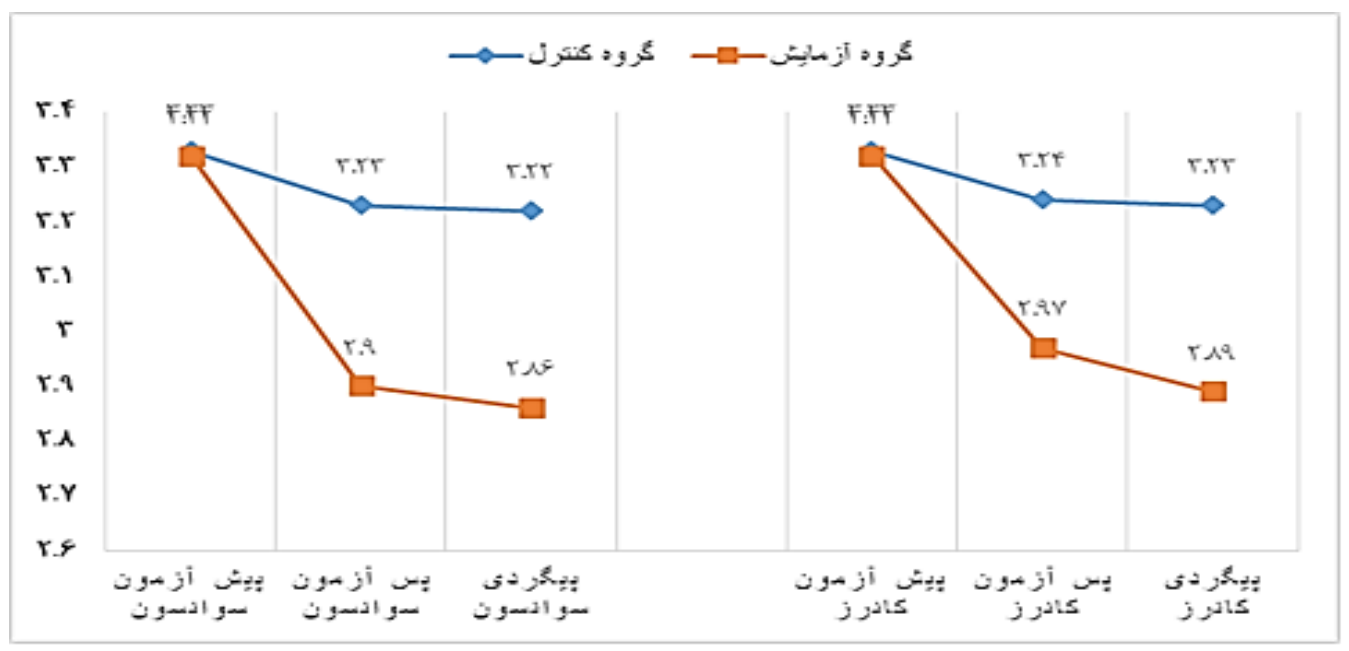

نمودار ا مقايسه ميانكين نمرات آزمون سوانسون و كانرز

نتايج جدول شماره Y مربوط به يافتهاى آزمون تحليل واريانس مركب مىباشد.

جدول ץ يافتهاى مربوط به آزمون تحليل واريانس مر كب

\begin{tabular}{|c|c|c|c|c|c|c|c|}
\hline توان & مجذور & سطح & مقدار F & مجانكين & درجادى & مجذوروات & منبع تغييرات \\
\hline $1 /$ & .1911 & $\cdot / \cdots 1^{*}$ & $F V / I Y I$ & $1 / \cdot r$ & $1 / 499$ & 1/01r & زمان اندازهكيرى \\
\hline$\cdot / 91$ & $\cdot / r \wedge q$ & $\cdot / \cdots 1^{*}$ & $19 / .94$ & $\cdot / 49 \Delta$ & 1 & $\cdot / 49 \Delta$ & تروه \\
\hline.$/ 99$ & $\cdot / 4 \cdot r$ & $\cdot / \cdots 1^{*}$ & $r \cdot / l V$. & $\cdot|A F|$ & $1 / 499$ & $.194 \lambda$ & زمان * كروه \\
\hline
\end{tabular}


به دليل اينكه اثر تعاملى (زمان اندازه گيرى ** گروه) معنادار است، از اثرات اصلى صرف نظر مى گردد. جدول

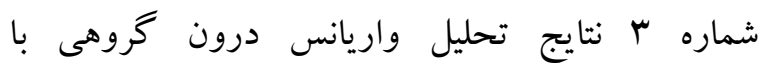
اندازهيرى تكرارى روى عامل مراحل اندازه گيرى براى مشخص نمودن تأثير آموزش شطرنج بر علائم بيش فعالى/ نقص توجه در دانش آموزان ورزشكار داراى اختلال بيش فعالى / نقص توجه را نشان مىدهد.
همانطور كه در جدول Y مشاهده مى كنيد، يافتهاى مربوط به آزمون تحليل واريانس مركب نشان داد كه اثر 6 اصلى زمان اندازه (F=FV/IY

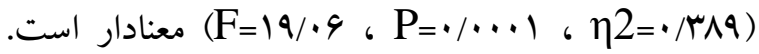
علاوه بر اين، تعامل زمان اندازه گيرى با كروه

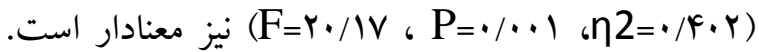

جدول ب تحليل واريانس درون كروهى با اندازهيرى تكرارى براى مقايسه نمرات علائم ييش فعالى /كمبود توجه (كانرز)

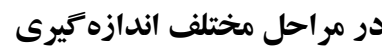

\begin{tabular}{|c|c|c|c|c|c|c|}
\hline توان & مجذور اتا & معنى سطح & Fقدار F F F & آزادى درجه & مجذانكين & كروه \\
\hline $1 /$ & - Naf &.$/ \cdots 1$ & $\Delta V / 99 Y$ & 1/ATr & $1 / 1 M F$ & كروه آموزش شطرنج \\
\hline$\cdot / 4 \cdot \Delta$ & $\cdot / / 11$ & $\cdot / \cdot M$ & $r / r \cdot V$ & $1 / . r 4$ & .1 .91 & كروه كنترل \\
\hline
\end{tabular}

ورزشكار داراى اختلال بيش فعالى / نقص توجه با توجه به معنادار بودن آزمون كرويت مو كلى (1/./. مى گردد. (F=0V/99 (P= شاخصهاى (F) مربوط به اثر گرين هاوس گيسر مشخص كردن جايگاه تفاوتهاى موجود در مراحل كزارش شد. با توجه به جدول ب نتايج آزمون تحليل اندازه گيرى از آزمون بيخردى بنفرونى استفاده گرديد كه

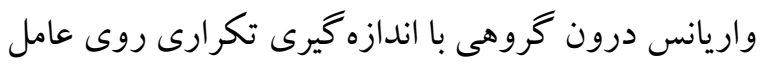
يافتهاى آن در جدول F كز ارش شده است.

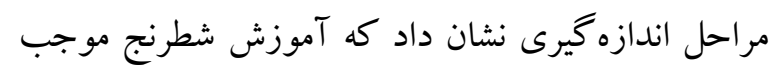
بهبود علائم بيش فعالى / نقص توجه در دانش آموزان

جدول ع يافتهاى آزمون بنفرونى به منظور بررسى جايعاه تفاوتهاى كروه آزمايش طى زمانهاى مختلف اندازه آحيرى

\begin{tabular}{|c|c|c|c|c|}
\hline سطح معنىدارى & خطاى استاندارد & اختلاف ميانكين & مراحل (J) & مراحل (I) \\
\hline.$/ \cdots 1^{*}$ & $\cdot / \cdot \Delta V$ & $\cdot \pi \Delta \Delta$ & ״ָ זٓزمون & \multirow[t]{2}{*}{ بيش آزمون } \\
\hline$\cdot / \cdots 1^{*}$ & $.1 . \Delta 9$ & - kar & يِيكردى & \\
\hline.$/ F V$ & $\cdot / \Delta F$ & $\cdot / M$ & بيكردى & یָ آزمون \\
\hline
\end{tabular}

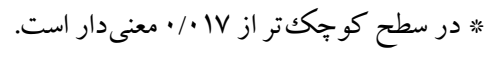

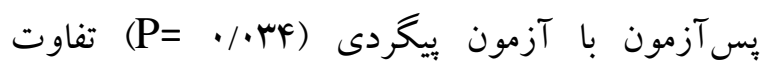

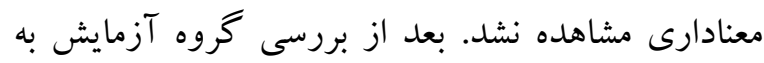

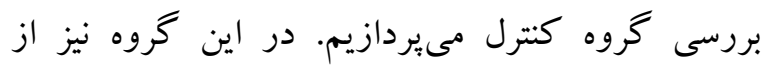
آزمون تحليل واريانس درون گروهى با اندازهيرى
همانطور كه در جدول F مشاهده مىشود نتايج آزمون

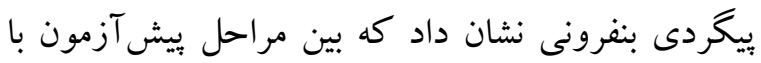

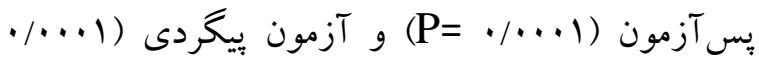
تفاوت معنادارى وجود دارد؛ اما بين مراحل (P= 
آل داو و همكاران (Y.|Y)، بلاسكو و همكاران (Y. (Y)؛ جوزف و همكاران، (Y) (Y)؛ جوز و همكاران، (Y) (Y.19)،

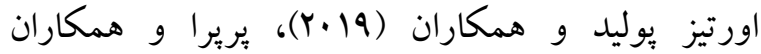
(Y.Y.) يافتهاى آنها نيز نشان داد كه استفاده از شطرنج در كاهش علائم و توانبخشى شناختى دانش آموزان و كودكان بيش فعال/نقص توجه اثركذار بوده است.

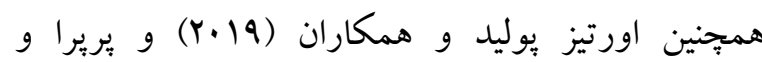

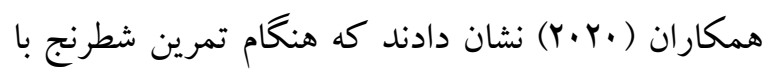
شدتهاى مختلف، قشر مغز خصوصاً قشر بيش ويشانى همان متناسب با شدت تمرين فعال مىشود و اين شدت در بزرگكسالان و نوجوانان متفاوت است و نتايج نشان دهنده تأثير شطرنج بر كاهش علائم و بهبود تو انايىهاى شناختى در افراد مخصوصاً كود كان و نوجوانان بود؛ كه اين نتيجه

$$
\text { هم با نتايج يزووهش همسو است. }
$$

در تبيين اثربخشى آموزش شطرنج بر كاهش علائم بيش فعالى / نقص توجه مىتوان عنوان كرد كه با توجه به

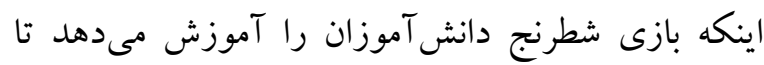
وقت خود راصرف انتخاب بهترين حركت كنند ؛بنابر اين منجر به شكيبايى، يشتكار، تمركز و خلاقيت بيشتر در اين

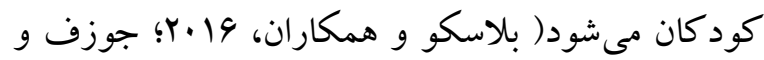
همكاران، 19 19؛ جوز و همكاران، 19 (Y). همجِنين اين بازى با تغيير مداوم و بیىديى توجه در طول بازى به

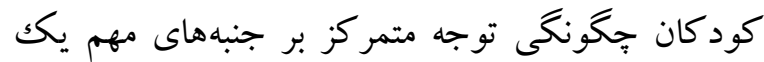
فعاليت براى بردازش مناسب را آموزش مىدهد. همجينين جون شطرنج باعث فعال سازى قشر مغز خصوصاً قشر

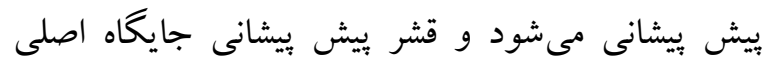
كاركردهاى اجرايى در مغز است و كاركردهاى اجر ايى فرايندهايى شناختى هستند كه فعاليت هاى شناختى ازجمله
تكرارى روى عامل مراحل اندازهگيرى استفاده گرديد. نتايج اين آزمون نشان داد كه بين مراحل اندازهيرى درى درى

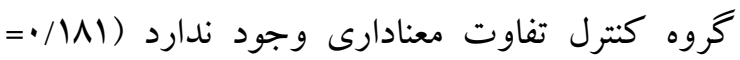
( $\mathrm{F}=\mu / \mu \cdot \vee{ }_{6} \mathrm{P}=\cdot / \cdot \Lambda_{1} \eta^{2}$

اين بثوهش با هدف بررسى مقايسهاى آموزش شطرنج بر علائم دانش آموزان مبتلا به بيشفعالى / نقص توجه انجام شد. همانطور كه در بخش يافتها بيان گرديد، بر اساس نتايج به دست آمده از هر دو ابزار اندازهگيرى سوانسون و كانرز و همبستخى مستقيم و بالاى گزارش شده بين آنها در بخش يافتهاى يثزوهشى، آموزش شطرنج منجر به كاهش علائم اين دانش آموزان شده است كه اين يافته با ليا اكثر يثوهشهاى انجام شده همسو است. براى مثال يثزوهشهاى انجام شده توسط بلاسكو و همكاران

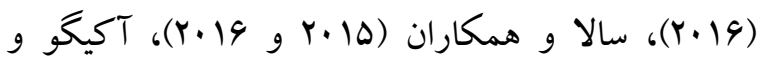

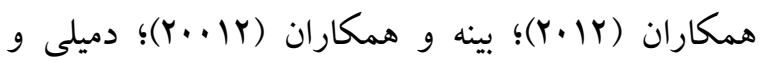

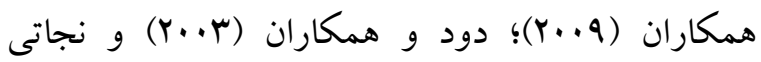
(1) (1) نشان داد كه آموزش شطرنج تأثير مثبى بر كاهش علائم كود كان بيش فعال و بهبود تو جه آنها دارد با توجه به نتايج به دست آمده مىتوان بيان كرد كه جون درمانهاى مبتنى بر بازى باعث انكيزه بيشترى براى شركت در درمان مىشوند و آموزش شطرنج به عنوان يكك بازى بر كاهش اين علائم مؤثر بوده است؛ بنابراين

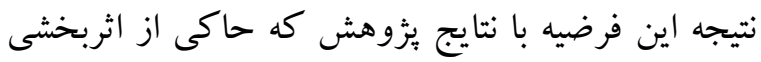
آموزش شطرنج بر علائم بيش فعالى / نقص توجه است

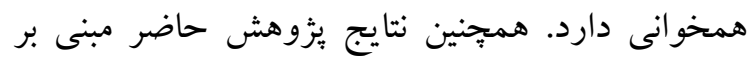
اثربخشى آموزش شطرنج بر علائم بيش فعالى / نقص توجه همسو با نتايج مطالعات جوز و همكاران (Y) (Y)، 
علت خستكى ناشى از وجود استراتزىهاى بيجزيده شناختى در شطرنج كه باعث خسته شدن و افزايش ميزان بى توجهى كودكك مىشود ديده نشد و همين مىتواند. يكى از عوامل تأثير گذار بر ايجاد انخيزه در كود كان و و درنتيجه تأثير مؤثر آن و علت نا همسو بودن نتايج با نهو ئزوهش هاى نامبرده باشد.

\section{نتيجه كيرى}

مطالعه حاضر حاكى از اثربخش بودن آموزش شطرنج در كاهش علائم بيش فعالى / نقص توجه بود؛ لذا در مراحل مختلف درمان يا بِ از آن مىتوان با آموزش و تمرين شطرنج به كاهش نشانگان ناشى از بيش فعالى /

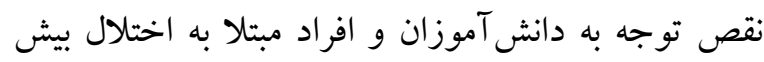
فعالى / نقص توجه كمك كرد. در اين يُوهش آموزش شطرنج به عنوان يكك بازى شناختى توانست بسيارى از علائم بيش فعالى / نقص توجه بيماران را كاهش دهد و موجب افزايش توان آنها براى ساز گارى با شرايط ليط ليمان

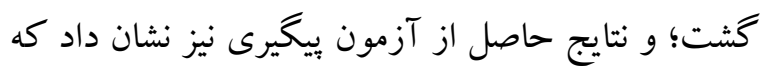
نتايج به دست آمده از ئزوهش بعد از كذشت دو هفته

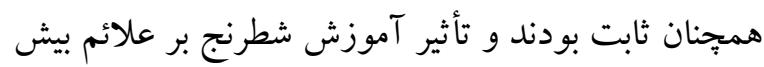
فعالى / نقص توجه ثابت باقى مانده است و علت اين

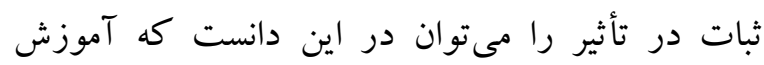
شطرنج بهعنوان يكك بازى شناختى به علت تغيير مداوم و يى در بیى توجه آزمودنىها در طول بازى و همجنين توجه متمركز بر جنبههاى مهم فعاليت مؤثر واقع شده است. علاوه بر اين به علت اينكه آموزش شطرنج در مقايسه با ساير درمانهاى اختلال بيش فعالى / نقص توجه، كم هزينهتر بود و عوارض جانبى نداشت كودكان و والدين به راحتى آن را يذيرفتند جر اكه كود كان بسيارى
توجه را هدايت مى كنند ببنابراين منجر به بهبود عملكرد شناختى و كاهش علائم بيش فعالى / نقص توجه در اين افراد مىشود. - اد. در بزوهش حاضر نيز كود كان و والدين آموزش شطرنج را به علت ارزانتر بودن نسبت به ساير روش درمانى موجود و نداشتن عوارض جانبى روانشناختى يا اثر ناكافى دركك شده، داروهاى بيش فعالى / نقص توجه به راحتى يذيرفتند. علاوه بر اين، بازى ابزارى مهم براى

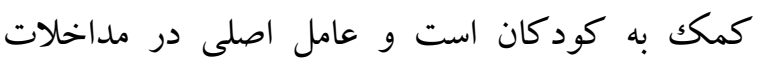
مبتنى بر بازى توانايى بازىها در ايجاد انگگيزه در كود كان

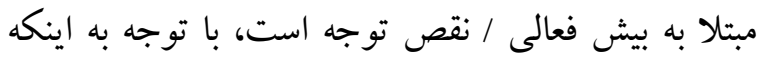
انكگيزه براى موفقيت در هر درمانى حياتى است. جاى تعجب نيست كه مداخلات مبتنى بر بازى همجِون

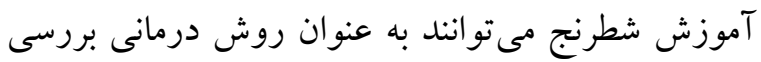

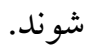
نتايج يزوهش حاضر با نتايج اسلام و همكاران (19) (Y)،

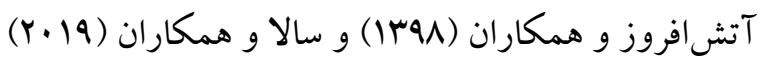
كه نشان دهنده عدم تأثير شطرنج بر كاهش علائم بيش فعال/ نقص توجه و توانايىهاى شناختى مىباشند ناهمسو است در بررسى اين نتايج مىتوان بيان كرد؛ كه برنامههاى آموزشى شناختى مثل شطرنج عملكردهاى شناختى را تقويت نمى كند و در بهترين حالت جنين مداخلاتى عملكرد فرد را در فعاليتهايى شبيه فعاليت آموزش دادهشده تقويت مى كند كه اين نتايج با نتيجه به دست آمده از يثوهش ناهمسو است و مىتوان علت را در روش، نوع مداخله و آزمودنىهاى ئزوهش دانست در يزوهش حاضر شطرنج توسط سيستم هوشمند (يروز كتور و تابلو هوشمند لمسى) و با استفاده از تابلوهاى آموزشى مخصوص اين رشته به كود كان آموزش داده شد به همين 
آموزشى و درمانى در مدارس و جلسات درمانى اين كود كان قرار كيرد.

سياسگز ارى

IR.SSRI.REC.1398.511 اين مطالعه با كد اخلاق مورد تأييد كميته اخلاق بزوهشكده تربيت بدنى و علوم ورزشى است. بدين وسيله از بروفسور استيفن هينشاو ' از

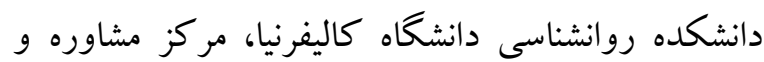
روانشناختى آموزش و يرورش استان لرستان، شهرستان خرم آباد و تمامى كود كان عزيزى كه به ما در اجراى اين

$$
\text { يُزوهش يارى رساندند تشكر مىنماييم. }
$$

\section{References}

Aciego R, Garcia L, Betancort M. (2012). The benefits of chess for the intellectual and socialemotional enrichment in schoolchildren. The Spanish journal of psychology, 15(2), 551559.

Alves D. (2019). The impact of ADHD in academic and socioemotional adjustment: multimodal interventions. Paper presented at the 5th International Congress of Clinical and Health Psychology on Children and Adolescents: book of abstracts.

Amouzadeh F, Hasanvand S, Hashemiyan K, Hemayattalab R. (2016). A comparison between effects of game and pharmacotherapy upon the improvement of the attention span and gross motor skills in children with attention deficit hyperactivity disorder(ADHD). Motor Behavior, 8(23), 97 110. (InPersian)

Asgari Nekah S, Abedi Z. (2014). The Effectiveness of Executive Functions based Play Therapy on improving Response Inhibition, planning and working memory in children with Attention Deficit Hyperactivity Disorder. Journal of
به علت عوارض ناشى از ساير درمانهاى اين اختلال، درمان را ادامه نمىدهند و اين باعث نتايج منفى بر عملكرد آنها مىشود.

در اين بثزوهش براى جلو گيرى از كاهش انگيزه و كسل شدن دانش آموزان در بازى، بازى شطرنج توسط سيستم هوشمند (يروز كتور و تابلو هوشمند لمسى) و با استفاده از تابلوهاى آموزش مخصوص اين رشته آموزش داده شدند همجنين براى كنترل متغيرهاى مزاحم و سو گيرىهاى احتمالى، آزمودنىها به صورت تصادفى به دو كروه آزمايش و كنترل تقسيم شدند و خروه كنترل در آموزش بح به به شطرنج براى كنترل تأثير مداخله (جهت كسب اطمينان بيشتر نسبت به اثربخشى مداخله) شركت نكرد؛ اما مهمترين محدوديت اين يثزوهش استفاده از روش نمونه كيرى در دسترس و محدود شدن نمونه آن به دانش آموزان مبتلا به بيش فعالى / نقص توجه شهر خرم آباد بود. همجنين وضعيت روحى آزمودنى ها در روز و ساعت آزمون و تجارب قبلى كود كان مورد مطالعه كه اندازه گيرى نشده بود مىتواند از عوامل اثر گذار بر اين يثزوه باشد؛ بنابراين بيشنهاد مىشود در تعميم يافنها جانب احتياط رعايت شود و براى بثوهشهاى آتى از روشهاى نمونه كيرى تصادفى استفاده كنند و همبجنين اقدام به يثوهشهاى مقايسهاى اين روش با ساير روشها مانند دارويى، رفتارى و غيره كنند. علاوه بر اين، آزمودنىهاى اين هئوهش همخَى مبتلا به اختلال بيش فعالى / نقص توجه بودند بيشنهاد مىشود مطالعات ديخرى روى آزمودنىهايى كه مبتلا به اختلالات ديخر هستند انجام شود تا مشخص گردد كه آيا نتايج آن مطالعات نيز با نتايج اين يزوهش همخوان است يا خير؟ همجينين يِيشنهاد مىشود آموزش شطرنج در برنامه

\footnotetext{
${ }^{1}$ - Stephen P.Hinshaw
} 
Cognitive Psychology, 2(1), 41-51.(In Persian)

Association AP. (2013). Diagnostic and statistical manual of mental disorders (DSM-5®): American Psychiatric Pub.

Atashafrouz AJIE. (2019). The Effectiveness of Chess on Problem-Solving, Working Memory, and Concentration of Male High School Students. JournalEP. 1(4), 249-259. (In Persian)

Barnard-Brak L, Sulak TN, Fearon DD. (2011). Coexisting disorders and academic achievement among children with ADHD. Journal of Attention Disorders, 15(6), 506515.

Bell AS. (2011). A critical review of ADHD diagnostic criteria: What to address in the DSM-V. Journal of Attention Disorders, 15(1), 3-10.

Binev S, Attard-Montalto J, Deva N, Mauro M, Takkula H. (2012). On the introduction of the programme 'Chess in School' in the educational systems of the European Union. Strasbourg: European P arliament.

Blasco-Fontecilla H, Gonzalez-Perez M, Garcia-Lopez R, Poza-Cano B, Perez-Moreno MR, De Leon-Martinez V, Otero-Perez J. (2016a). Efficacy of chess training for the treatment of ADHD: A prospective, open label study. Revista de Psiquiatría y Salud Mental (English Edition), 9(1), 13-21.

Caye A, Swanson JM, Coghill D, Rohde LAJMP. (2019). Treatment strategies for ADHD: an evidence-based guide to select optimal treatment. 24(3), 390-408.

Conners C, Sitarenios G, Parker J, Epstein J. (1998). Conners CK, Sitarenios G, Parker JD, Epstein JN. The revised Conners' Parent Rating Scale (CPRS-R): factor structure, reliability, and criterion validity. J Abnorm Child Psychol 26: 257-268. Joumal of abnormal child psychology, 26, 257-268. do: 10.1023/A:1022602400621

Cordier R, Bundy A, Hocking C, Einfeld S. (2009). A model for play-based intervention for children with ADHD. Australian Occupational Therapy Journal, 56(5), 332-340.

De Joode BvW, Mora AM, Lindh CH, HernándezBonilla D, Córdoba L, Wesseling C, Mergler
DJC. (2016). Pesticide exposure and neurodevelopment in children aged 6-9 years from Talamanca, Costa Rica. 85, 137-150.

Demily C, Cavézian C, Desmurget M, BerquandMerle M, Chambon Vr, Franck N. (2009). The game of chess enhances cognitive abilities in schizophrenia. Schizophrenia research, 107(1), 112-113.

Dowd S, Davidhizar R. (2003). Can mental and physical activities such as chess and gardening help in the prevention and treatment of Alzheimer's? Healthy aging through stimulation of the mind. The Journal of practical nursing, 53(3), 11.

El Daou BM, El-Shamieh SI. (2015). The effect of playing chess on the concentration of $\mathrm{ADHD}$ students in the 2nd cycle. 192, 638-643.

Ferguson R. (1995). The USA Junior Chess Olympics Research: Developing Memory and Verbal Reasoning. The Benefits of Chess in Education, 81-85.

Hall CL, Guo B, Valentine AZ, Groom MJ, Daley D, Sayal K, Hollis C J. (2019). The validity of the SNAP-IV in children displaying ADHD symptoms. 1073191119842255 .

Hazell P, Lewin T, Sly K. (2005). What is a clinically important level of improvement in symptoms of attention-deficithyperactivity disorder? Australian and New Zealand journal of psychiatry, 39(5), 354-358.

Islam A, Lee WS, Nicholas A. (2019). The Effects of Chess Instruction on Academic and NonCognitive Outcomes: Field Experimental Evidence from a Developing Country.

Janatian S, NOURI AA, Shafti S, Moulavi H, Samavatian H. (2008). Effectiveness of play therapy on the bases of cognitive behavior approach on severity of symptoms of Attention Deficit/Hyperactivity Disorder (ADHD) among primary school male students aged 9-11.

Jose S, Abraham RJ, Education I. (2019). Influence of Chess and Sudoku on Cognitive Abilities of Secondary School Students. 7(1), 27-34. 
Joseph E, Easvaradoss V, Kennedy A, Kezia E. (2016). Chess training improves cognition in children. GSTF Journal of Psychology, 2(2), 1-6.

Kiani B, Hadianfard H. (2016). Psychometric properties of a persian self-report version of Swanson, Nolan and Pelham rating scale (version IV) for screening attention-deficit/hyperactivity disorder in adolescents. Iranian Journal of Psychiatry and Clinical Psychology, 21(4), 317-326. (In Persian)

Krinzinger H, Hall CL, Groom MJ, Ansari MT, Banaschewski T, Buitelaar JK, Reviews B. (2019). Neurological and psychiatric adverse effects of long-term methylphenidate treatment in ADHD: A map of the current evidence. 107, 945-968.

Moreira M, Reis M, Silva S, Alves D, Henriques M. (2019). The case of João: attention deficit hyperactivity disorder and tourette's syndrome comorbidity. Paper presented at the 5th International Congress of Clinical and Health Psychology on Children and Adolescents: book of abstracts.

Nechio DE. (2016). Chess Practice and Executive Functioning in a Post-Secondary Student Diagnosed with ADHD: A Single Case Study. University of Saskatchewan.

Nejati VJ. (2020). Cognitive rehabilitation in children with attention deficit-hyperactivity disorder: Transferability to untrained cognitive domains and behavior. 49, 101949. (In Persian)

Noda S, Shirotsuki K, Nakao MJ. (2019). The effectiveness of intervention with board games: a systematic review. 13(1), 22.

Ortiz-Pulido R, Ortiz-Pulido R, Garcia-Hernández LI, Perez-Estudillo CA, Ramirez-Ortega MLJ. (2019). Neuroscientific evidence support that chess improves academic performance in school. 20(4), 194-199.

Pereira T, Castro MA, Villafaina S, Carvalho Santos A, Fuentes-Garcia JP. (2020). Dynamics of the Prefrontal Cortex during Chess-Based Problem-Solving Tasks in CompetitionExperienced Chess Players: An fNIR Study. 20(14), 3917.
Sabzevari H, Arsham S, Parvinpour S. (2019). Effect of Eight Weeks of Rhythmic Motor Games on Motor Proficiency, Aggression, and Academic Achievement in Children with Attention Deficit Hyperactivity Disorder. The Scientific Journal of Rehabilitation Medicine, 8(4), 236-246. doi: 10.22037/jrm.2019.111905.2124

Sala G, Gobet F. (2016). Do the benefits of chess instruction transfer to academic and cognitive skills? A meta-analysis. Educational Research Review, 18, 46-57.

Sala G, Gobet FJ. (2019). Cognitive training does not enhance general cognition. 23(1), 9-20.

Sala G, Gorini A, Pravettoni G. (2015). Mathematical problem-solving abilities and chess: an experimental study on young pupils. Sage Open, 5(3), 2158244015596050.

Salami F, Ashayeri H, Estaki M, Farzad V, Koochak, ER. (2016). Mother-Based Combination Training and Its Effect on the Symptoms Attention Deficit/Hyperactivity Disorder (ADHD). (In Persian)

Seilsepour M, Hamounpeyma E, Pirkhaefi A. (2015). The effect of Neurofeedback therapy sessions on female elementary students with attention deficit and hyperactivity in varamin city, in 2013. Navid No, 18(60), 24-33. (InPersian)

Spencer T, Biederman J, Wilens T, Harding M, O'donnell D, Griffin S. (1996). Pharmacotherapy of attention-deficit hyperactivity disorder across the life cycle. Journal of the American Academy of Child \& Adolescent Psychiatry, 35(4), 409-432.

Subia GS. (2020). Treasure Chess: Worthy Contributions of the Game in the Lives of Student Champions. 14(1).

Toomey SL, Sox CM, Rusinak D, Finkelstein JA. (2012). Why do children with ADHD discontinue their medication? Clinical Pediatrics, 51(8), 763-769.

Trinchero R. (2016). Does chess instruction enhance mathematical ability in children? A threegroup design to control for placebo effects. Paper presented at the 38th Annual Meeting of the Cognitive Science Society. 
Wolraich ML, Chan E, Froehlich T, Lynch RL, Bax A, Redwine ST, Hagan JF. (2019). ADHD diagnosis and treatment guidelines: a historical perspective. 144(4), e20191682. 